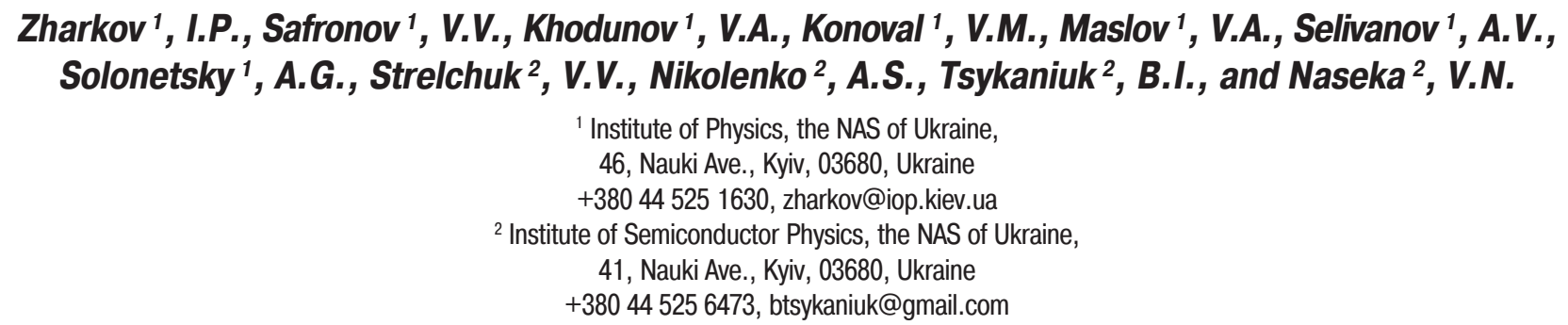

\title{
DEVELOPMENT OF SPECIALIZED MANIPULATORS FOR LOW TEMPERATURE RESEARCH
}

Introduction. Magneto- and electro-optical research of materials at cryogenic temperature requires expensive specialized cryostats. In the case of research in magnetic fields up to $1 \mathrm{~T}$ special manipulator holders can be used.

Problem Statement. Design of special manipulators for cryostats to enable the magneto-optical research of materials under the action of external magnetic and electric fields is a relevant problem for low temperature studies.

Purpose. The purpose is to develop specialized manipulators for electro- and magneto-optical measurements at cryogenic temperature.

Results. Special sample holding manipulators have been developed. They enable to conduct low-temperature measurements at cryogenic temperature in a constant magnetic field up to $1 \mathrm{~T}$ in liquid-flow cryostat. The design enables varying the field by changing the gap between the magnets. The magnetic field direction is changeable with respect to the direction of light propagation.

The developed manipulator makes it possible to study the optical properties of materials depending on applied electric field, at low temperature and to supply electric field to the samples, as well as to record electrical signals from the sample. The use of sample holding manipulators enables measuring several samples in one cycle of cryostat fill.

Conclusion. Special manipulators have been designed to study the magneto- and electro-optical properties of materials at low temperature. With the help of developed manipulators, it is possible to measure the influence of magnetic and electric field on the optical properties of the materials studied.

The research has been carried out within the framework of the Program of Research Instrument-Making of the NAS of Ukraine, grant No. P- 2/16-40.

Keywords: manipulator, magneto-optics, electro-optics, and cryostat.

Nowadays, the use of sample holders in cryostats for low temperature research is rather widespread [1-8]. The holders help carrying out various researches inasmuch as they enable sample measurements under the action of various factors (electric and magnetic fields, compression, stretching, etc.). In

(C) ZHARKOV, I.P., SAFRONOV, V.V., KHODUNOV, V.A., KONOVAL, V.M., MASLOV, V.A., SELIVANOV, A.V., SOLONETSKY, A.G., STRELCHUK, V.V., NIKOLENKO, A.S., TSYKANIUK, B.I., and NASEKA, V.N., 2018 addition, using these holders, researchers can record additional information signals from samples.

Usually, for low temperature electro- and magneto-optical studies researchers apply special cryostats. To create a magnetic field these cryostats can employ special superconductive solenoids [7], rods with induction coil [6] or be directly located in the field of an external magnet [3]. One of the problems with the use of such cryostats in research is their high cost. Therefore, while con- 


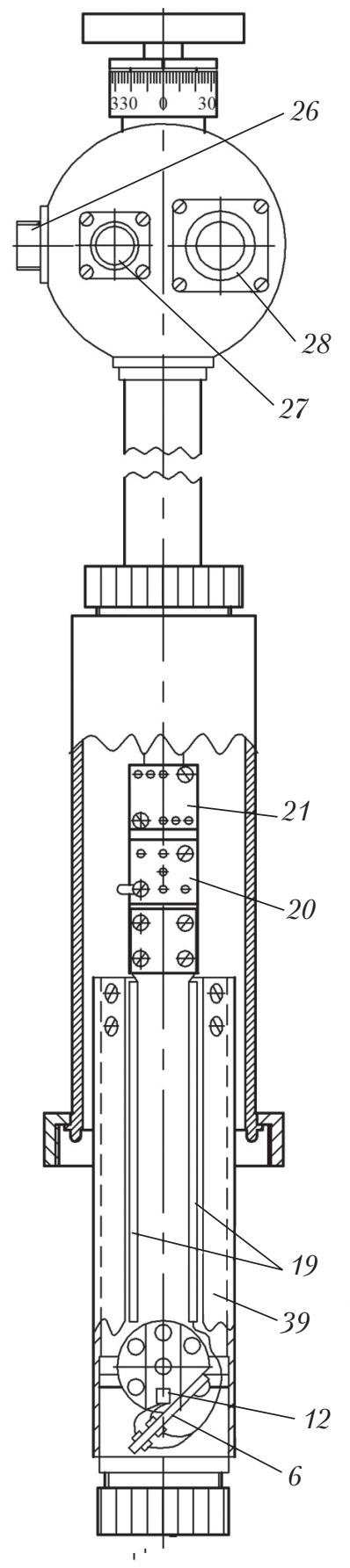

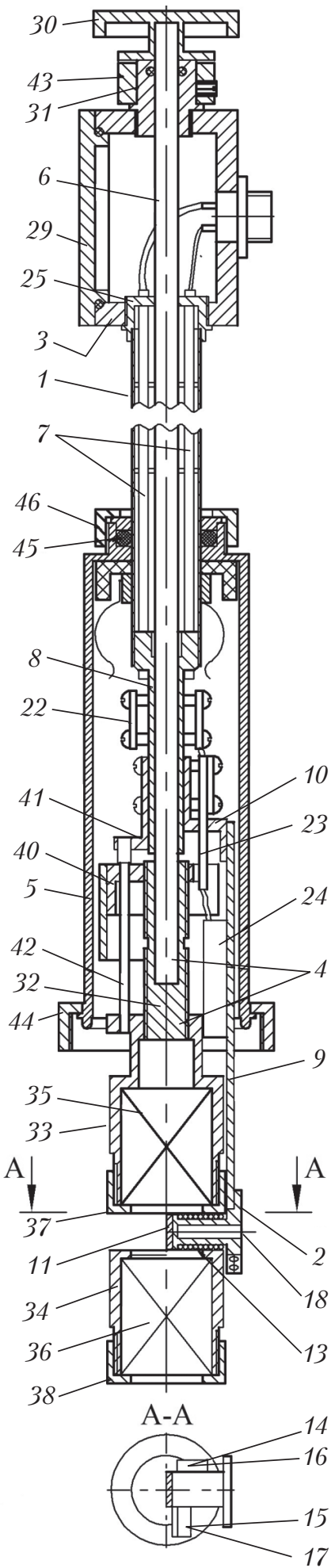

Fig. 1. Configuration of magneto-optical manipulator ducting optical studies under small magnetic field (for example, studying the Zeeman effect) or applying an external electric field, to use in the optical cryostat a sample holder located in the field between two permanent magnets can be an alternative solution. The purpose of this research is to develop special manipulators for electro- and magneto-optical research at cryogenic temperature.

Fig. 1 shows a configuration of manipulator for magneto-optical research. The proposed manipulator enables using $20 \mathrm{~mm}$ diameter neodymium magnets to create radially and axially oriented magnetic fields up to $1 \mathrm{~T}$. It consists of a central tube 1 , a base plate 2 to fasten the sample, a junction box 3, a mechanism 4 for moving constant magnets, and an extension bar 5 . The tube 1 is a thin-walled tube made of material having a low heat conductivity, with a rotatable slide rod 6 of the mechanism for moving magnets fixed inside. The mechanism for spatial parallel drawing of magnets by means of two screw pairs with the right and the left threads transforms the rod rotational movement around the vertical axis into the synchronous translational motion in opposite directions of two circuits with magnets. Also, within the tube 1 , there are fixed four tubes 7 with smaller diameter of the two circuits with magnets. The conductors connecting the sample, the heater, the temperature sensor, the Hall sensors, and the capacitive level meter with the connectors in the junction box 3 run through these tubes.

In the proposed manipulator for magneto-optical research, the sample 11 is fixed on the face end of the base plate 2 and located along the manipulator vertical axis. The base plate 2 is fixed on the shank 8 in the lower part of the tube 1 through the plate 9 and the bracket 10 . On the base plate, there are mounted a temperature sensor 12 and an electric heater coil $13(R=15 \mathrm{ohm} \pm 20 \%)$. In addition, it bears plates 14 and 15, with two Hall sensors 16, 17 mounted thereon. The former (16) is used to measure the radially oriented magnetic field, while the latter (17) is to measure the axially oriented magnetic field. The base plate 2 has a hatch 18 for doing optical research. 
The conductors from the sample, the heater, the Hall sensors, and the temperature sensors run through the tubes 19 to the switching cards 20, 21 and 22 and are connected to the conductors running through the tubes 7 to the connectors on the junction box 3 . In addition, the conductor 23 from the capacitive level meter 24 passes through one of the tubes 7 and is connected to respective connector on the junction box. The junction box 3 is fixed in the upper part of the central tube 1 using the plug 25 and is used for mounting the connectors 26, 27, and 28. To ensure access to connector contacts, there is a detachable cover 29. The scheme for connection of electric circuits to the connector contacts is given in Fig. 2.

To vary the magnetic field strength between the constant magnets, the mechanism 4 is used. It consists of a flywheel 30 stiffened in the upper part of the rod 6 . The flywheel and the sliding rod can revolve in the boss 31. Also, the mechanism includes a screw 32 with right- and left-hand thread fixed in the lower part of sliding rod and cartridges 33, 34, with constant magnets 35, 36 fastened by car screws 37 and 38 . The cartridge 33 has a right-hand thread in the upper part and is mounted in the lower part of the screw 32 . When the screw rotates clockwise the cartridge together with the magnet 35 moves upward. The cartridge 34 through the tube 39 is fixed on the upper part of the screw 32 using the left-hand thread nut 40. As the screw 32 rotates clockwise, the cartridge 34 with the magnet 36 mounted in it moves downward. Thus, while the flywheel 30 rotating clockwise the distance between the magnets 35 and 36 with respect to the sample synchronously increases, whereas if the flywheel moves counterclockwise the distance decreases.

For convenience of magnetic field strength calibration based on screw rotation angle a special mechanism has been designed. It works as follows: on the shank 8 , there is a fixed angle piece 41 with a guide 42 for the cartridge 33 and the nut 40 . On the boss 31 , there is the limb 43 for counting the rotation angle of the sliding rod 6 with the screw 32. The latter has left- and right-

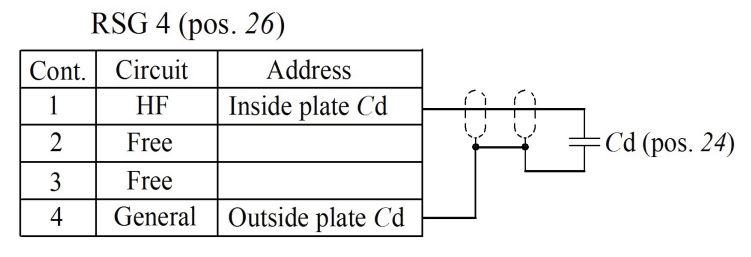

RSG 7 (pos. 27)

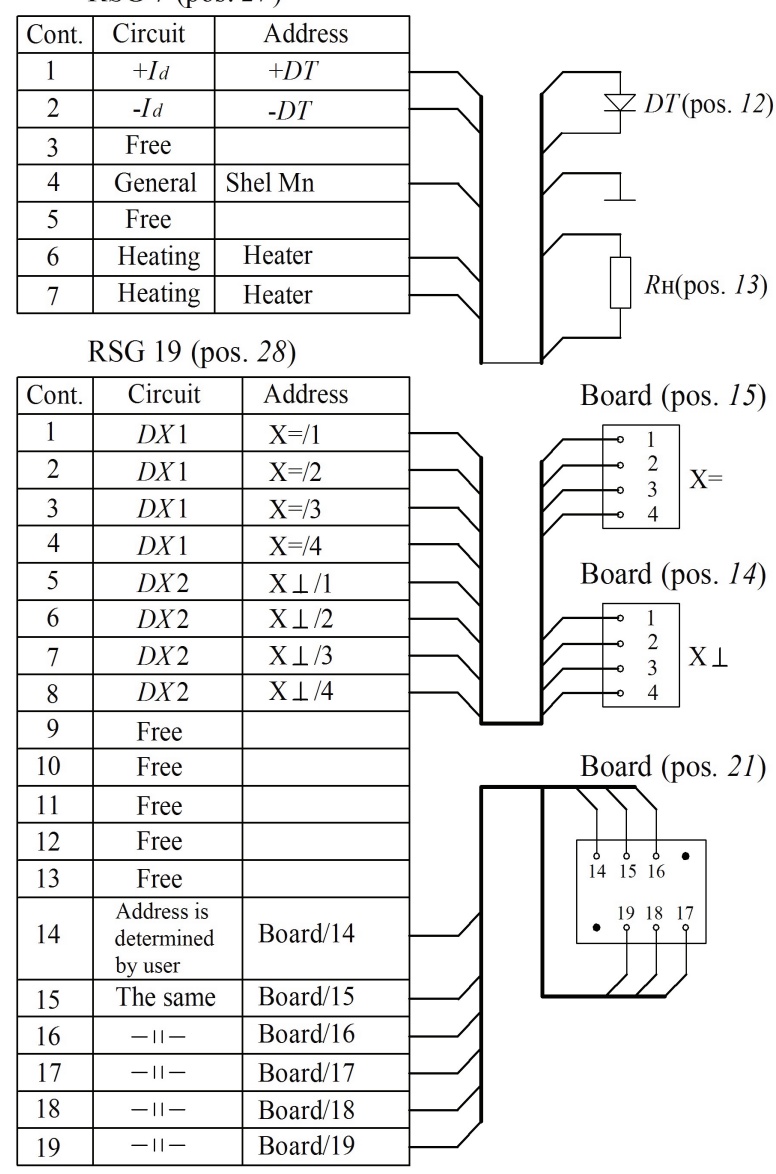

Fig. 2. Scheme of connection of electric circuits on the manipulator for magneto-optical research

handed thread with a step of $1 \mathrm{~mm}$. The extension bar 5 is fixed on the upper nipple of the cryostat using the nut 44. In the packer 45, the tube 1 can move upward or downward and spin a full $360^{\circ}$. The tube 1 position is fixed using the nut 46. Per one full spin of the screw the distance between the magnets can increase or decrease by 2 $\mathrm{mm}$. Dependence of magnetic field strength on distance between $10 \mathrm{~mm}$ and $20 \mathrm{~mm}$ thick magnets is shown in Fig. 3. 


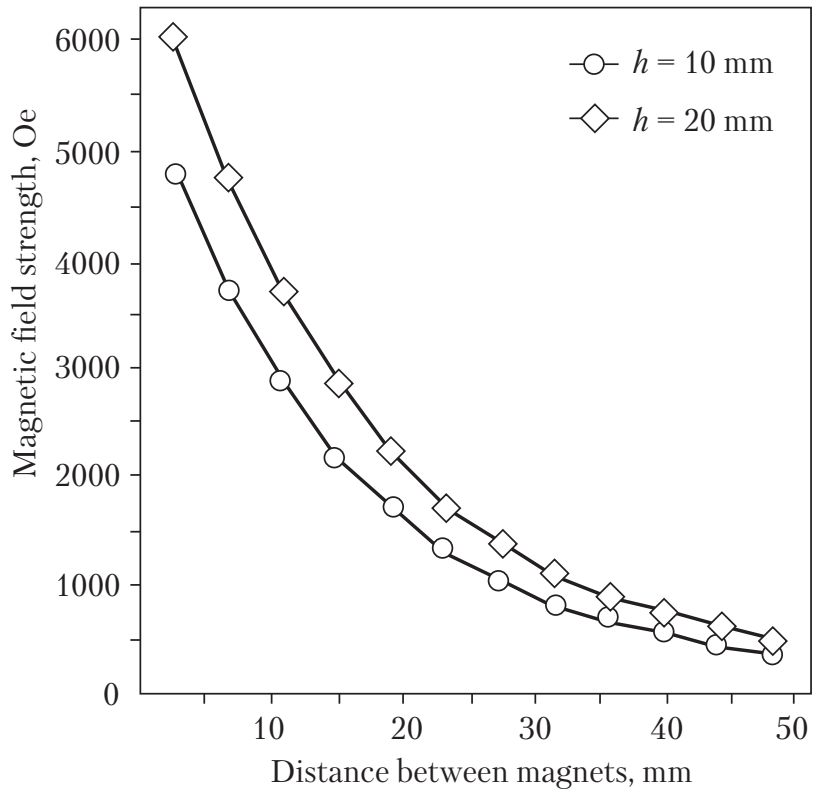

Fig. 3. Dependence of magnetic field strength on distance between constant magnets of different height $(h=10 \mathrm{~mm}, h=20 \mathrm{~mm})$

The manipulator enables low temperature (4.2 K) magneto-optical measurements of transmission, absorption, reflection, photo- and electroluminescence spectra, within a wide IR range $(0.8-300$ $\mu \mathrm{m})$. In addition, it is possible to measure the spectra of magnetic circular dichroism in the IR range in the two different geometries: Faraday (wave vector $k$ of incident light is parallel to magnetic field strength $H$, magnetic circular dichroism) and Voigt (wave vector $k$ is perpendicular to vector $H$, magnetic linear dichroism).

Using the manipulator, various magneto-optical effects, including the Zeeman effect in semiconductors doped with atoms of transition $3 d$ metals, can be studied. The study of spectral dependence of Zeeman effect enables determining the value and character of Zeeman splitting to understand the type and cause of interaction between the magnetic impurities. Due to controllable magnetic field and its calibration using the Hall sensors, the manipulator can be used for measuring dependence of the described magnetooptical effects on magnetic field strength.

To design and to produce the devices it is necessary to know their behavior under the influence of various external factors, including optical radiation, temperature, electric current, etc. Therefore, in this research, a manipulator for electrooptical studies has been configured and manufactured (Fig. 4). It enables working with samples placed in Plcc 20 pins (Plastic leadless chip carrier) and with flat samples of arbitrary shape with maximum cross size of $15 \mathrm{~mm}$.

The manipulator consists of a central tube 1 , detachable base plates 2 to fasten the samples, a junction box 3 , an extension bar 4 and a mechanism for moving the holder 2 along and around the vertical axis. The tube 1 is a thin-walled tube made of material having a low heat conductivity, with four less tubes 6 with conductors running through it. These conductors connect the sample, the heater, the temperature sensor, and the capacitive level meter with connectors on the junction box 3 .

The holder of replaceable plates 2 with samples is fastened in the shank 7 in the lower part of the tube 1 . The holder also bears the temperature sensor 8 and the sensor 10 of helium capacitive level meter fastened with the clamp 9. The holder 2 has four screw holes for replaceable base plates with samples. Also, in the lower part of the holder, there is electric heater $11(R=21 \mathrm{ohm} \pm 20 \%)$.

The junction box 3 is mounted in the upper part of the tube 1 through the plug 12 and used for installing the connectors $13,14,15$. To ensure access to connector contacts, there is a detachable cover 16. The manipulator is mounted on the upper nipple of the cryostat using the extension bar 4 fixed with the cap screw 17 . The tube 1 is located in the upper part of the extension bar and can rotate and move in vertical direction. The tube position is fixed with the help of packer 18 using the screw cap 19. The special device 20 ensures centering the lower part of manipulator in the thermostat chamber and while placing it in the cryostat. The foam-rubber plug 21 limits the volume of thermostat chamber with the manipulator from upside.

To move the holder 2 vertically and around the axis, a special mechanism has been designed. It 
consists of a cup 22 fixed in the upper part of the extension bar 4 and a fixation mechanism. The fixation mechanism consists of the clamp 23 mounted on the tube 1 , the bar 24 , the case 25 in which the axis 26 and the spring 27 are fixed, and the flywheel 28 fastened on the axis. The clamp 23 is mounted on the tube 1 using the screw 29. The mechanism 5 is to move the holder 2 in three fixed positions along the height and around the axis, which are defined by positions of nine holes in the cup 22.

To start the work, the manipulator must be set in its original position. In this position, the axis 26 passes through the bottom home of the cup 22, with the vertical cross section of the fixation mechanism located in the plane of vertical cross section of the holder 2. In the case of such ar-

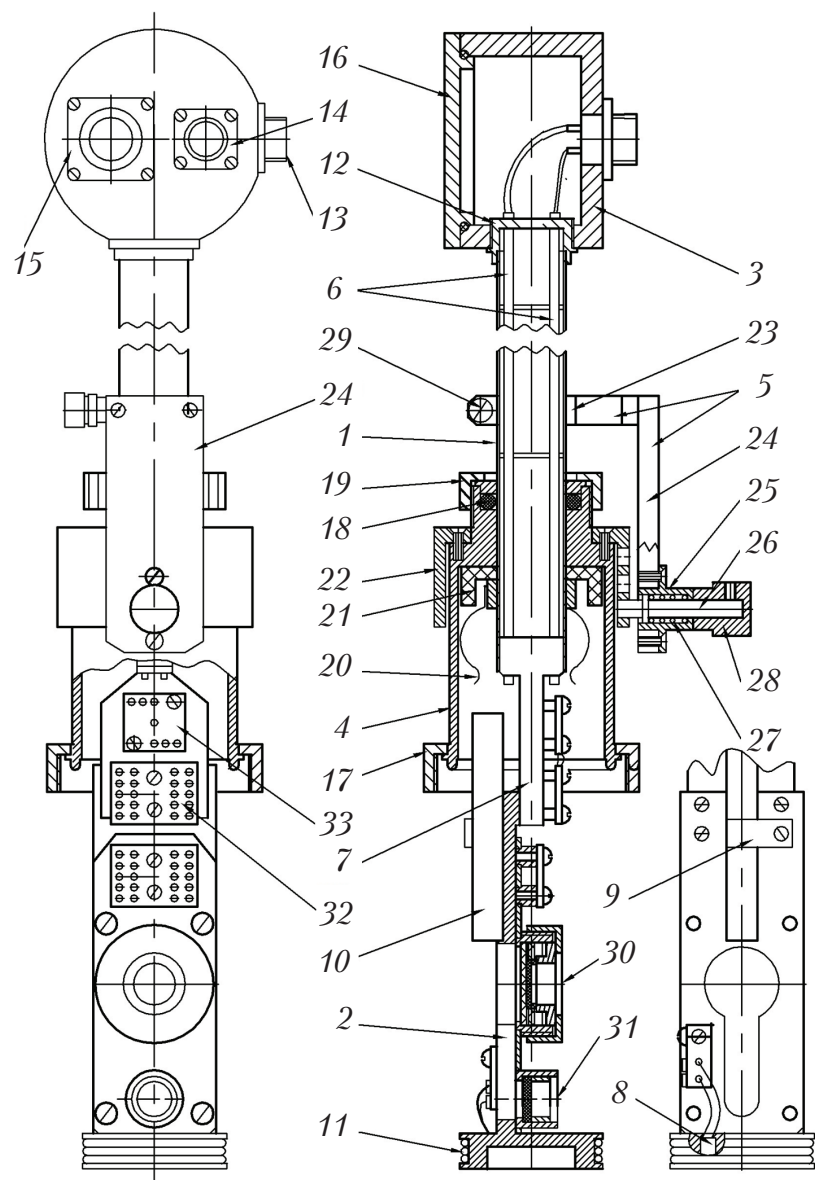

Fig. 4. Configuration of electro-optical manipulator

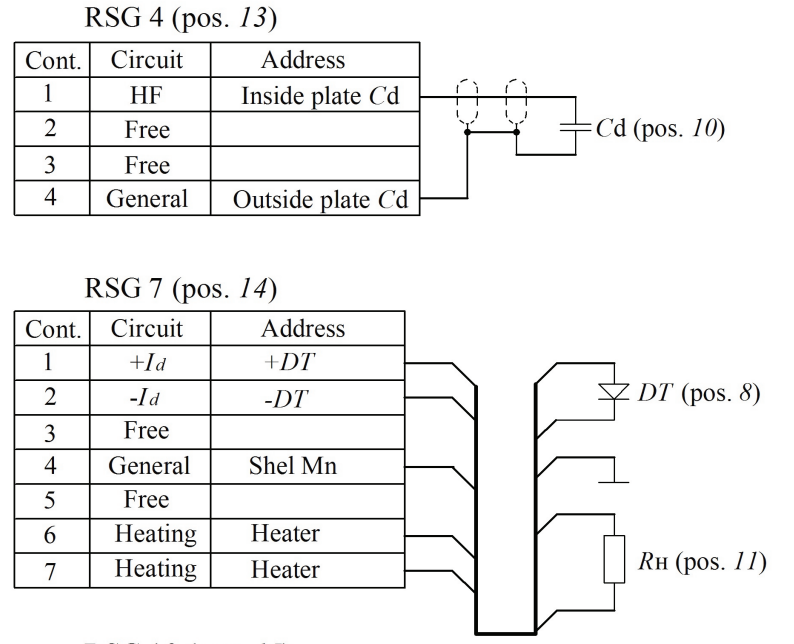

RSG 10 (pos. 15)

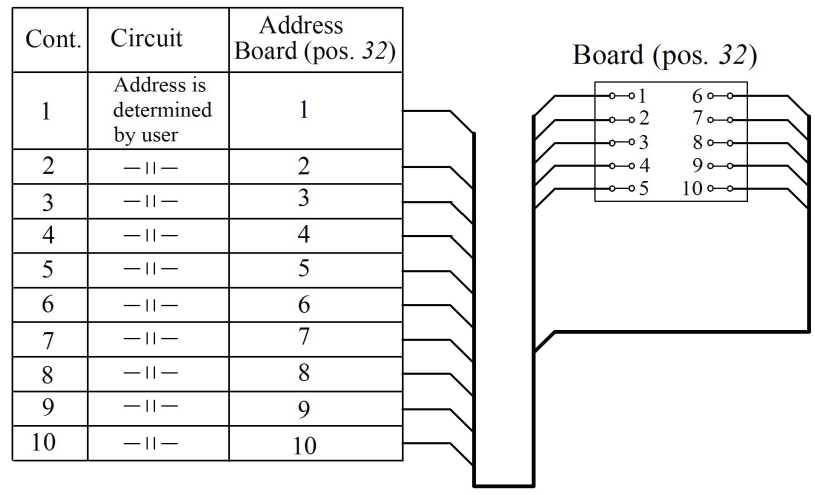

Fig. 5. Scheme of connection of electric circuits on the manipulator for electro-optical research

rangement, the lower position of axis 26 in the cup 22 corresponds to the position of upper hole 30 of the base plate, which is on the optical axis of cryostat window.

To move the holder 2 in the second fixed position it is necessary to loosen the nut 19 and to raise the axis 26 in the cup 22 using the flywheel 28. The bottom hole 31 of the base plate rises by $22 \mathrm{~mm}$. In the case of base plate with three holes it is necessary to move the holder 2 up by 10.5 $\mathrm{mm}$ and to fix the axis 26 in the hole of the cup 22. If required, in addition to moving vertically, the holder 2 can spin $90^{\circ}$ on either side. The leads from the samples, the temperature sensor, the capacitive meter, and the heater are connected with the junction box using the switching cards 32, 33. 
The scheme of connection of electric circuits to the connector contacts is shown in Fig. 5.

Vertical movement of manipulator and its fixation in certain positions enable studying several samples in one working cycle of helium filling. Due to this, neither heating of cryostat nor its depressurization for replacement of sample is required, which significantly reduces both time of measurements and consumption of energy and cryogenic liquids. In addition, adjustable posi- tion of manipulator by height and around the axis enables additional adjustment of the sample position in the cryostat with respect to direction of incident light. This makes it possible to study certain local areas of the sample. The possibility to connect electric contacts to the sample enables doing simultaneously electro-physical, optical, and electro-optical research.

The intellectual property has been protected by patents of Ukraine No. 120275 and No. 120401.

\title{
REFERENCES
}

1. Deklaratsiinyi patent na korysnu model Ukrainy \# 17466. Zharkov I.P., Maslov V.O., Safronov V.V., Chmul A.H. Vstavka kriostata [in Ukrainian].

2. Patent Ukrainy N44265 na korysnu model. Zharkov I.P., Zhyrko Yu.I., Komarov A. V., Maslov V.O., Safronov V.V. Vstavka kriostata [in Ukrainian].

3. Zharkov, Y.P., Zhyrko, Yu.Y., Yvashchenko, A.N., Safronov, V.V., Khodunov, V.A. (2010). Termorehulyruemaia kryostatnaia systema dlia yssledovanyia mahnyto-optycheskykh svoistv materyalov pod davlenyem v dyapazone temperatur 77-300 K. Nauchnoe pryborostroenye, 20(2), 120-125 [in Russian].

4. Patent Ukrainy N 55606 na korysnu model. Zharkov I.P., Maslov V.O., Khodunov V.O., Safronov V.V., Chmul A.H. Vstavka kriostata dlia doslidzhennia fotovoltaichnykh kharakterystyk zrazkiv pry mekhanichnykh navantazhenniakh [in Ukrainian].

5. Patent Ukrainy na vynakhid N 103508. Zharkov I.P., Komarov A.V., Maslov V.O., Safronov V.V. Vstavka kriostata dlia elektromahnitooptychnykh doslidzhen [in Ukrainian].

6. Patent Ukrainy na korysnu model N 86176. Zharkov I.P., Maslov V.O., Safronov V.V., Selivanov O.V. 3D vstavka kriostata dlia optychnykh ta elektrooptychnykh doslidzhen [in Ukrainian].

7. Patent Ukrainy na oynakhid N 112992. Zharkov I.P., Pylypchuk O.S., Poroshyn V.M., Safronov V.V., Khodunov V.O. Termorehulovana kriostatna systema dlia mahnitofizychnykh ta elektrofizychnykh doslidzhen [in Ukrainian].

8. Zharkov, I.P., Safronov, V.V., Palamarchuk, S.P., Pylypchuk, O.S., Solonetskyi, A.H., Khodunov, V.O. (2016). Kompleks krioaparatury z vbudovanym nadprovidnym solenoidom dlia mahnitofizychnykh ta elektrofizychnykh doslidzhen. Nauka innov., 12(3), 29-34 [in Ukrainian].

Received 14.11.17

\author{
І.П. Жарков ${ }^{1}$, В.В. Сафронов ${ }^{1}$, В.О. Ходунов ${ }^{1}$, В.М. Коновал ${ }^{1}$, В.О. Маслов ${ }^{1}$, О.В. Селіванов ${ }^{1}$, \\ А.Г. Солонецький ${ }^{1}$, В.В. Стрельчук ${ }^{2}$, А.С. Ніколенко ${ }^{2}$, Б.І. Циканюк ${ }^{2}$, В.М. Насєка ${ }^{2}$ \\ ${ }^{1}$ Інститут фізики НАН України, проспект Науки, 46, Київ, 03680, Україна, \\ +380 44525 1630, zharkov@iop.kiev.ua \\ ${ }^{2}$ Інститут фізики напівпровідників НАН України, проспект Науки, 41, Київ, 03680, Україна, \\ +380 44525 6473, btsykaniuk@gmail.com

\section{СТВОРЕННЯ СПЕЦІАЛІЗОВАНИХ МАНІПУЛЯТОРІВ ДЛЯ НИЗЬКОТЕМПЕРАТУРНИХ ДОСЛІДЖЕНЬ}

Вступ. Дослідження магніто- та електрооптичних властивостей матеріалів в умовах кріогенних температур потребує високовартісних спеціалізованих кріостатів. У випадку проведення досліджень в магнітних полях з індукцією до 1 Тл можна використовувати спеціальні вставки-тримачі.

Проблематика. Розробка спеціальних маніпуляторів для кріостату, які б дозволяли проводити дослідження оптичних властивостей матеріалів під впливом зовнішнього магнітного та електричного полів - це важлива проблема при проведенні низькотемпературних досліджень. 
Мета. Створення спеціалізованих маніпуляторів для електро- та магнітооптичних вимірювань в умовах кріогенних температур.

Результати. Розроблено спеціальні маніпулятори-тримачі зразків, які дозволяють проводити вимірювання в умовах кріогенних температур у постійному магнітному полі з індукцією до 1 Тл в кріостаті рідинно-проточного типу. Конструкція також передбачає можливість змінювати величину поля шляхом зміни величини зазору між магнітами. Додатково є можливість змінювати напрямок ліній напруженості магнітного поля відносно напрямку поширення світла.

Розробка дозволяє виконувати дослідження оптичних властивостей матеріалів залежно від прикладеного електричного поля в умовах низьких температур, а також передбачає можливість підведення електричного поля до зразків та реєстрацію електричних сигналів від зразка. Використання розроблених тримачів дає можливість проводити вимірювання декількох зразків в одному циклі заливки кріостату.

Висновки. Розроблено спеціальні маніпулятори для дослідження магнітооптичних та електрооптичних властивостей матеріалів в умовах низьких температур, що дають можливість виконувати вимірювання впливу магнітного та електричного поля на оптичні властивості досліджуваних матеріалів.

Роботу виконано в рамках програми наукового приладобудування НАН України, грант П-2/16-40.

Ключові слова: маніпулятор, магнітооптика, електрооптика, кріостат.

$$
\begin{aligned}
& \text { И.П. Жарков }{ }^{1} \text {, В.В. Сафронов }{ }^{1} \text {, В.А. Ходунов }{ }^{1} \text {, В.М.Коновал }{ }^{1} \text {, В.А. Маслов }{ }^{1} \text {, А.В. Селиванов }{ }^{1} \text {, } \\
& \text { А.Г. Солонецкий }{ }^{1}, \text { В.В. Стрельчук², А.С. Николенко }{ }^{2} \text {, Б.И. Цыканюк², В.Н. Насека }{ }^{2} \\
& { }^{1} \text { Институт физики НАН Украины, просп. Науки, 46, Киев, 03680, Украина } \\
& \text { +380 } 44525 \text { 1630, zharkov@iop.kiev.ua } \\
& { }^{2} \text { Институт физики полупроводников НАН Украины, просп. Науки, 41, Киев, 03680, Украина } \\
& \text { +380 } 44525 \text { 6473, btsykaniuk@gmail.com } \\
& \text { СОЗДАНИЕ СПЕЦИАЛИЗИРОВАННЫХ МАНИПУЛЯТОРОВ } \\
& \text { ДЛЯ НИЗКОТЕМПЕРАТУРНЫХ ИССЛЕДОВАНИЙ }
\end{aligned}
$$

Введение. Исследование магнито- и электрооптических свойств в условиях криогенных температур требует дорогостоящих специализированных криостатов. В случае проведения исследований в магнитных полях с индукцией до 1 Тл можно использовать специальные вставки-держатели.

Проблематика. Разработка специальных манипуляторов для криостата, позволяющих проводить исследования оптических свойств под воздействием внешнего магнитного и электрического полей - это важная проблема при проведении низкотемпературных исследований.

Цель. Создание специализированных манипуляторов для электро- и магнитооптических измерений в условиях криогенных температур.

Результаты. Разработаны специальные манипуляторы-держатели образцов, которые позволяют проводить измерения в условиях криогенных температур в постоянном магнитном поле с индукцией до 1 Тл в криостате жидкостно-проточного типа. Конструкция также предусматривает возможность изменять величину поля путем изменения величины зазора между магнитами. Дополнительно есть возможность менять направление линий напряженности магнитного поля относительно направления распространения света.

Разработка позволяет выполнять исследования оптических свойств в зависимости от приложенного электрического поля в условиях низких температур, а также предусматривает возможность подведения электрического поля к образцам и регистрации электрических сигналов от образца. Использование разработанных держателей дает возможность проводить измерения нескольких образцов в одном цикле заливки криостата.

Выводы. Разработаны специальные манипуляторы для исследования магнитооптических и электрооптических свойств в условиях низких температур, позволяющие выполнять измерения влияния магнитного и электрического поля на оптические свойства исследуемых материалов.

Ключевые слова: манипулятор, магнитооптика, электрооптика, криостат. 


\section{SUBSCRIPTION} 2018
The Science and Innovation Journal has been published over ten years. The Journal is focused on the innovation policy, the results of basic and applied research conducted by the institutes of the National Academy of Sciences of Ukraine, the national universities, and other research institutions in Ukraine.

In 2007, the Journal launched a new section Protection of Intellectual Property highlighting the issues of legal protection of intellectual property rights, the state system of legal protection, the information support of activities in the field of intellectual property, as well as the experience and problems of invention and innovation support.

The Journal can be subscribed through Ukrinformnauka subscription agency. The subscription fee is:

\section{UAH 225.00 for 6 months; UAH 450.00 for 12 months.}

To subscribe the Journal, please, fill out the order form and send it to the Agency by mail, fax or email.

\begin{tabular}{|l|l|}
\hline \multicolumn{2}{|c|}{ SUBSCRIPTION 2018} \\
\hline Subscriber & \\
\hline Address & \\
\hline Postal delivery address & \\
\hline Beneficiary & \\
\hline $\begin{array}{l}\text { Contact person (full name, telephone, } \\
\text { fax, e-mail) }\end{array}$ & \\
\hline The period of subscription & \\
\hline Number of copies & \\
\hline
\end{tabular}

For subscription please, contact: tel./fax: +380 442880346 ;

mob. tel.: +380 501547783

E-mail: innovation@nas.gov.ua

Mailing address: 54 Volodymyrska St.,

Kyiv, 01601, Ukraine 